ISSN 0103-5150

Fisioter. Mov., Curitiba, v. 29, n. 3, p. 581-588, Jul./Set. 2016

Licenciado sob uma Licença Creative Commons

DOI: http://dx.doi.org.10.1590/1980-5918.029.003.A016

\title{
Motor development of preterm and term infants in the fundamental movement phase: a cross-sectional study
}

\author{
Desenvolvimento motor de crianças nascidas pré-termo e a \\ termo na fase motora fundamental: um estudo transversal
}

Joyce Karla Machado da Silva, Aline Mariane Sargi, Isabel Cristina de Oliveira Andrade, Camila Costa de Araújo, Tiago Del Antonio*

Universidade Estadual do Norte do Paraná (UENP), Jacarezinho, PR, Brazil

\begin{abstract}
Introduction: Motor development is a continuous process of motor behavior changes throughout life, allowing for movement control. Premature birth can affect this process, with a greater risk of delays in acquiring these skills. Objective: Compare motor development during the fundamental movement phase of preterm infants submitted to early stimulation and full-term babies. Methods: An analytical cross-sectional study with convenience sampling, performed with twenty 3-year-old children of both sexes, distributed into two groups: the preterm group $(\mathrm{n}=10)$, which received physical therapy in the first months of life, and the term group $(\mathrm{n}=10)$. Motor development stages were assessed between January and April 2013, using the Motor Development Scale (Escala de Desenvolvimento Motor - EDM) developed by Francisco Rosa Neto, with an average execution time of thirty minutes. Statistical analysis was performed using BioEstat 5.0 software, and the Shapiro-Wilk test was applied to verify data normality. A significance level of $\mathrm{p} \leq 0.05$ was adopted, analyzed using the Mann-Whitney test. Results: The term group exhibited significant differences in relation
\end{abstract}

*JKMS: MS, e-mail: jksilva@uenp.edu.br MAS: BS, e-mail: alinesargi@gmail.com ICOA: BS, e-mail: isabel.coa@gmail.com CCA: MS, e-mail: camilaaraujo@uenp.edu.br TODA: MS, e-mail: tiagodantonio@uenp.edu.br 
to the preterm group for the variables Fine and Gross Motor Skills, and Spatial and Temporal Awareness, with no differences in Balance and Body Scheme. Conclusion: Only the premature infants submitted to early intervention achieved normal levels of Balance and Body Scheme on the EDM Scale.

Keywords: Child Development. Motor Skills. Term Birth. Premature Birth.

\section{Resumo}

Introdução: Desenvolvimento motor é um processo contínuo de alterações do comportamento motor ao longo da vida, permitindo controle de movimentos. $O$ nascimento prematuro pode ser um evento que acarrete implicações ao processo, com maior risco para atrasos na aquisição das habilidades. Objetivo: Comparar o desenvolvimento motor de crianças nascidas prematuras estimuladas precocemente e crianças nascidas a termo, na fase motora fundamental. Métodos: Estudo transversal analítico, de conveniência, realizado com 20 crianças na faixa etária de 03 anos, de ambos os sexos, distribuídas em dois grupos, grupo pré-termo $(n=10)$ o qual, durante os primeiros meses receberam intervenção fisioterapêutica e grupo a termo $(n=10)$. As fases do desenvolvimento motor foram avaliadas através da Escala de Desenvolvimento Motor (EDM), desenvolvida por Francisco Rosa Neto, com execução média de trinta minutos, entre janeiro e abril de 2013. A análise estatística dos resultados foi realizada através do pacote BioEstat 5.0 e para verificar a normalidade entre os dados utilizou-se o Teste de Shapiro-Wilk. Em relação ao padrão de significância adotou-se o valor de p $\leq 0,05$, analisado por meio do teste de Mann-Whitnney. Resultados: O grupo a termo demonstrou diferenças significativas quando comparado com o grupo pré-termo nas variáveis Motricidade Fina e Global, na Organização Espacial e Temporal, não apresentando discrepância de valores nas variáveis Equilíbrio e Esquema Corporal. Conclusão: Somente os prematuros que receberam a intervenção precoce conseguiram alcançar níveis estabelecidos como normais nas variáveis Equilíbrio e Esquema Corporal da Escala EDM.

Palavras-Chave: Desenvolvimento Infantil. Habilidade Motora. Nascimento a Termo. Nascimento Prematuro.

\section{Introduction}

Motor development is a continuous sequential process whereby humans progressively acquire a significant number of motor skills. Motor behavior begins with simple, disorganized skills and evolves to a level of movement involving complex and organized patterns (1).

Children born after 37 weeks of gestation are considered full term, that is, birth occurred within the physiologically stipulated period. Preterm or premature babies are those born before 37 weeks (WHO) $(2,3)$. In these children, developmental delays and problems will be more severe $(4,5)$. They may also exhibit neurosensory dysfunctions that can be identified in the early stages. However, mild developmental disturbances may go unnoticed until preschool or elementary school age $(6,7)$.

Fundamental movements are gross motor skills commonly required in the daily lives of children and mastered during childhood. The fundamental movement stage occurs from the age of two to seven years and follows on from the rudimentary movements of the neonatal period.

Fundamental movements include exploration, control of discrete, serial and continuous movements and testing the body's motor skills. Also included are locomotors movements (running and jumping), manipulative skills (throwing and catching), and stability skills, which involve balance and coordination (8).

Some aspects can negatively affect child development, including prematurity, low birth weight and environmental factors. Perceptual, motor and attention deficits as well as behavioral disorders are often associated with premature birth. As such, early intervention and developmental monitoring serve as instruments in the prevention of possible disturbances among preterm children $(9,10)$.

A study that analyzed the effectiveness of physical therapy in premature infants found that proper physiotherapy could be an effective tool in facilitating skills acquisition (11).

The activities proposed in the child's family environment, via physiotherapy intervention, can 
promote experiences in different settings and attitudes that facilitate motor learning (12).

Research has identified the importance of monitoring preterm children after the first years of life, even when they do not exhibit high biological risk at birth or evidence of neurological impairment that may affect development $(7,13)$. The aim of the present study was to compare motor development during the fundamental movement phase of preterm infants submitted to early stimulation and full-term babies.

\section{Methods}

\section{Participants}

This was a cross-sectional analytical study with convenience sampling, approved by the institutional Research Ethics Committee under protocol no. 25296913.6.0000.0108. The sample was composed of 20 children of both sexes, aged 3 years. Of these 10 were born premature in the cities of Santo Antônio da Platina and Cambará (state of Paraná), and 10 were born full term in Jacarezinho/PR. Thus, participants were divided into 2 groups:

i. The Preterm Group (PG) of healthy children, six girls and four boys who, according to their medical charts based on neurological exams and pre-, peri- and postnatal history, showed no signs of functional disorders, a decisive factor in their inclusion. It is important to note that the Apgar score was not used and the gestational age of subjects was between 28 and 36 weeks. All the children participated in an early stimulation project developed by Universidade Estadual do Norte do Paraná (UENPCCS) in Jacarezinho (state of Paraná) and including cities from the Norte Pioneiro mesoregion (Andirá, Cambará, Carlópolis, Jacarezinho, Ribeirão Claro and Santo Antônio da Platina). Families received monthly home visits from previously trained physical therapy professors and students from the institution. Under the project physiotherapy intervention began from the first trimester of the child's life until independent walking was achieved and consisted of the application of protocols (instruction leaflet on how to properly perform stimulation according to the child's age and with the supervision of a physical therapist), as well as assessments (reflexes and reactions, exercises proposed in the leaflet, body weight, motor development) and reassessments once a month. ii. The Term Group (TG) consisted of ten healthy children born from 37 weeks onwards, with the same gender numbers and age as the Preterm Group, all enrolled in public preschools. Children diagnosed with cerebral palsy, intellectual disability, genetic, neurological and/or motor diseases with functional repercussions were excluded from the study.

\section{Material}

The motor development of the children was evaluated using the motor Development Scale (EDM) developed by Francisco Rosa Neto (14).

The EDM is an assessment instrument that encompasses different areas of development and consists of a set of tests graded according to the level of difficulty presented. The scale aimed is at children aged between two and twelve years, with and without developmental disorders.

Six batteries of tests were applied using similar methodology and including the following areas of human movement: (1) fine motor skills, (2) gross motor skills, (3) balance, (4) body scheme, (5) spatial awareness and (6) temporal awareness. Results were classified on a Total Motor Quotient (TMQ), obtained via the child's overall motor age and chronological age. Ratings fell into the following categories: Very high, High, High normal, Medium Normal, Low normal, Low and Very low, indicating overall performance in the tests.

\section{Procedures}

Data on the premature children were collected by analyzing the medical charts used by those responsible for the early stimulation project, who gave authorization to access the information. These documents were grouped according to the data assessed in the present study. The families of the children selected were contacted via home visits by researchers. After initially approaching parents and guardians, the researchers explained the study procedures and requested they provide written informed consent for application of the EDM. Permission to participate was refused for only one of the premature children. The researchers were unable to replace the child because the initial data collected identified all those eligible for this study, that is, children who were no longer 
taking part in the project (developed by Universidade Estadual do Norte do Paraná - UENP) and could therefore be assessed in the period after motor development stimulation.

Information related to full-term children was obtained by visiting a preschool selected beforehand by researchers because it fit the study profile in that it contained the same gender and number of prematurely born children. Following written authorization from the preschool's director, children were randomly selected and teachers acted as intermediates in sending written information to their parents. This leaflet described the study procedures and scale applicability, along with a consent form to be signed and returned to teachers, as well as a phone number for direct contact with the researchers to provide additional information and answer questions. The approach used for parents and guardians proved effective, with substantial study adherence immediately after initial contact, and only one participant was excluded from this group. However, this child was immediately replaced and both groups therefore contained the same number of children. Assessments were carried out at the preschool during the school day, at times stipulated by teachers and administrators so as not to interfere in students' school activities. Premature children were evaluated at home in a setting where motor tests could be applied with no external influences.

All the researchers were previously trained to ensure that assessments were standardized and prevent interferences in the study. For both groups assessed, candidate selection and data collection occurred from January to April 2013. The average time each participant needed to complete the motor tests was thirty minutes. All the children wore comfortable clothing that did not hamper their movements during assessment.

\section{Statistical analysis}

Motor development areas were evaluated in accordance with the Motor Assessment Manual (14). Based on the data obtained, mean and standard deviation were analyzed using Excel software for each motor skill of the PG and TG.

Statistical analysis was performed using BioEstat 5.0 software, and the Shapiro-Wilk test was applied to verify data normality. A significance level of $p=0.05$ was adopted, analyzed using the Mann-Whitney test.

\section{Results}

The results obtained in the present study are shown in table format and expressed as mean and standard deviation, separated by group (Preterm and Term Group).

The motor skills analyzed are show in order of result significance.

Table 1 - Comparison of Fine and Gross Motor Skills, Balance, Body Scheme Spatial and Temporal Awareness between the Preterm (PG) and Term Groups (TG)

\begin{tabular}{lcc}
\hline & $P G$ & TG \\
\hline Fine Motor Skills & $3.5 \pm 0.8$ & $4.7 \pm 1.3^{*}$ \\
Gross Motor Skills & $4.3 \pm 0.8$ & $5.2 \pm 0.6^{*}$ \\
Balance & $5.0 \pm 1.4$ & $5.5 \pm 1.0$ \\
Body Scheme & $4.4 \pm 0.7$ & $4.5 \pm 1.0$ \\
Spatial Awareness & $4.1 \pm 1.1$ & $5.6 \pm 1.3^{*}$ \\
Temporal Awareness & $3.6 \pm 1.3$ & $4.7 \pm 0.5^{*}$ \\
\hline
\end{tabular}

Note: Balance and Body Scheme ( $p \geq 0.05)$. Significant difference between PG X TG for Spatial and Temporal Awareness ( $\leq \leq 0.01)$. *Significant difference between PG X TG for Fine and Gross Motor Skills $(p \leq 0.05)$. 
Table 1 shows a significant difference between the PG and TG in the variables fine and gross motor skills.

Intergroup comparison for balance and body scheme found no statistically significant differences between the PG and TG.

With respect to spatial and temporal awareness, a statistically significant difference was observed for the TG in relation to the PG.
Thus, the Term Group exhibited significant differences in relation to the Preterm Group for the variables Fine and Gross Motor Skills, and Spatial and Temporal Awareness, with no differences in Balance and Body Scheme values.

The Total Motor Quotient (TMQ) of the EDM Scale classifies the children assessed according to the results of the tests applied, as shown in table 2 (14).

Table 2 - Intergroup comparison of the Classification and Total Motor Quotient (PG and TG)

\begin{tabular}{ccc}
\hline Classification/Motor Quotient & $\begin{array}{c}\text { Number of children PG } \\
(\mathbf{N}=10)\end{array}$ & $\begin{array}{c}\text { Number of children TG } \\
(\mathbf{N}=\mathbf{1 0})\end{array}$ \\
\hline Very High (130 or more) & 3 & 6 \\
High (120 to 129) & 1 & 2 \\
High Normal (110 to 119) & 2 & 1 \\
Medium Normal (90 to 109) & 3 & 1 \\
Low Normal (80 to 89) & 1 & 0 \\
Low (70 to 79) & 0 & 0 \\
Very Low (69 or less) & 0 & 0 \\
\hline
\end{tabular}

Note: Source: Research data.

Table 2 shows that most of the children in the preterm group are rated as Very High and Medium Normal, with the remainder ranging between High, High Normal and Low Normal. In the term group most participants were classified as Very High, with the remainder scoring between High, High Normal and Medium Normal. Thus, the results demonstrate that despite the differences between the groups, a considerable number of the premature children are classified at suitable levels for their age.

\section{Discussion}

Experiencing different environments helps children grow, develop and acquire new skills $(15,16)$. Acquiring motor skills depends on the task and quality of the stimulation provided, in combination with suitable physiotherapy programs $(17,18,19)$.

With respect to the motor skills related to balance and body scheme, differences were not marked in either group and were only significant for fine and gross motor skills, as well as temporal and spatial awareness. Nevertheless, comparisons indicated that the stimulated group fell within the average for their age when analyzed individually.

The results demonstrate that children from the PG achieved satisfactory development, possibly due to the opportunity to explore the environment provided by early intervention, with some intergroup differences in the abovementioned motor skills area.

It is important to note that the children studied are in the fundamental movement phase, which occurs from the age of two to seven years, and are therefore undergoing a significant motor skills learning process that differs from child to child $(9,20)$. In addition, there are no specific studies in the literature on the fundamental movement phase that include and discuss the motor assessment tests analyzed.

Premature children exhibited some delays in motor development; however, this may not be a decisive factor during development, since these can be modified in accordance with the quality of the environment provided (21). This was evident in the present study, where one monthly visit was sufficient to convey and fully apply all the guidelines in order to achieve our objectives. 
A study of hospitalized infants assessed the effects of a psychomotor program on development and found that stimuli provided by the researchers during intervention improved the children's motor skills, thus reinforcing the importance of changing the environment through professional guidelines tailored to each case (22).

The investigation analyzed the performance of premature children in the development of language, cognitive, self-care, socialization and motor skills. The authors concluded that monitoring overall development in conjunction with intervention programs minimized harmful effects on the motor development of these children (23).

Fundamental motor skills directly and significantly affect the overall motor performance of children, reinforcing the notion that children who fail to master these skills may be prone to developmental stagnation, requiring monitoring through several stages of development (7).

These results demonstrate the importance of early stimulation in premature children to prevent possible motor delays that could manifest themselves in any motor skills area.

In a study of premature and full-term newborns, the authors found that the premature children mastered overall motor coordination, suggesting that the intervention program used facilitated their development (24). This result corroborates the findings of the present study, where the average score in the TG was normal, while children in the PG scored mainly between medium normal and very high when analyzed separately, due to the combination of early intervention and external factors.

Children aged eight to ten years with learning difficulties were evaluated using the EDM scale and all its motor components. The authors concluded that all the children exhibited delayed motor development in most of the components assessed, emphasizing the need for early intervention to mitigate these effects (25).

Children's social lives, guidance by family members and a variety of age-appropriate objects and stimuli are important factors in the development of motor skills that drive the stimulus-response cycle $(26,27,28)$.

These data reinforce the importance of the present study, which demonstrated the acquisition of motor skills in premature children submitted to early stimulation, bringing them in line with those born full-term $(29,30)$.

\section{Study limitations}

Although research is fundamental in the field of motor development among preterm infants submitted to early stimulation, the present study applied convenience sampling because subjects formed part of the researchers' work environment, and inclusion criteria meant the sample size was small.

In addition to the small number of subjects in the experimental group submitted to early stimulation, this study and the assessments conducted were hampered by external factors such as problems locating individuals initially registered who were no longer residing at the addresses provided. Another limitation was the fact that the control group was not fully available to researchers during the study period, as well as the insufficient number of participants.

Thus, results were limited to the study sample and could not be extrapolated to other populations such as a control group. Nevertheless, this study served as the basis for further more in-depth research on the issue.

\section{Conclusion}

The analysis of motor development during the fundamental movement phase identified the acquisition of motor skills among premature children, primarily in relation to Balance and Body Scheme, with these subjects achieving the same standard as full-term infants and the opportunity of reaching normal levels. In the other variables assessed, premature children did not reach the same levels achieved by the TG.

As such, more in-depth investigations with larger sample sizes are suggested to assess the motor development of preterm children in the fundamental movement phase who were not submitted to early stimulation, due to the fundamental importance of constantly monitoring development in premature children.

Thus, the present study confirms the significance of including physical therapy in intervention programs aimed at providing information, practical tasks and constant monitoring, with subjects achieving 
overall motor gains over an appropriate and fully individualized period, making this study unique.

\section{References}

1. Willrich A, Azevedo CCF, Fernandes JO. Desenvolvimento motor na infância: influência dos fatores de risco e programas de intervenção. Rev Neurocienc. 2009;17:51-6. Portuguese.

2. Matos C, Martins F, Botelho M. A coordenação motora em crianças ex-prematuras e/ou nascidas de muito baixo peso. Acta Med Port. 2011;24(S2):12330. Portuguese.

3. World Health Organization (WHO). Nacimientos prematuros. Nota descriptiva $N^{\circ}$ 363. 2015 Nov. 2015 [cited Mar 17]. Available from: http://tinyurl.com/ hgebauy. Spanish.

4. Rodrigues OMPR, Silva ATB. Efeitos da prematuridade sobre o desenvolvimento de lactentes. Rev Bras Cresc Des Hum. 2011;21(1):111-21. Portuguese.

5. Zomignani AP, Zambelli HJL, Antonio MARGM. Desenvolvimento cerebral em recém-nascidos prematuros. Rev Paul Pediatr. 2009;27(2):198-203. Portuguese.

6. Nascimento DZ, Carvalho KP, Iwabe C. Perfil Cognitivo e Motor de Crianças Nascidas Prematuras em Idade Escolar: Revisão de Literatura. Rev Neurocienc. 2012;20(4):618-24. Portuguese.

7. Vieira EB, Linhares MBM. Desenvolvimento e qualidade de vida em crianças nascidas pré-termo em idades pré-escolar e escolar. J Pediatr. 2011;87(4):281-91. Portuguese

8. Gallahue, DL, Ozmun JC. Compreendendo o Desenvolvimento Motor: bebês, crianças, adolescentes, adultos. 3rd ed. São Paulo: Phorte; 2005. Portuguese.

9. Cardoso AA, Magalhães LC, Barbosa VM. Desenvolvimento psicomotor em crianças pré-termo e a termo na idade escolar. Rev. bras. crescimento desenvolv. hum. 2011;21(2):210-9. Portuguese.

10. Lemos RA, Frônio JS, Ribeiro LC, Demarchi RS, Silva J, Neves LAT. Desempenho funcional segundo a idade gestacional e o peso ao nascer de crianças em idade pré-escolar nascidas prematuras ou com baixo peso. Rev. bras. crescimento desenvolv hum. 2012;22(1):111. Portuguese.
11. Coutinho GAX, Lemos DM, Caldeira AP. Impact of physiotherapy on neuromotor development of premature newborns. Fisioter Mov. 2014;27(3):413-20.

12. Oliveira SMS, Almeida CS, Valentini NC. Programa de fisioterapia aplicado no desenvolvimento motor de bebês saudáveis em ambiente familiar. Rev Educ Fis UEM. 2012;23(1):25-35. Portuguese.

13. Magalhães LC, Catarina PW, Barbosa VM, Mancini MC, Paixão ML. Estudo comparativo sobre o desempenho perceptual e motor na idade escolar em crianças nascidas pré-termo e a termo. Arq NeuroPsiquiatr. 2003;61(2-A):250-5. Portuguese.

14. Neto FR. Manual de Avaliação Motora. Porto Alegre (Brazil): Artmed; 2002. p. 136. Portuguese.

15. Bueno EA, Castro AAM, Chiquetti EMS. Influência do Ambiente Domiciliar no Desenvolvimento Motor de Lactentes Nascidos Pré-Termo. Rev Neurocienc. 2014;22(1):45-52. Portuguese

16. Silva OPV. A importância da família no desenvolvimento do bebê prematuro. Psicol Teor Prat. 2002;4(2):1524. Portuguese.

17. Caetano MJD, Silveira CRA, Gobbi LTB. Desenvolvimento Motor de Pré-escolares no Intervalo de 13 meses. Brazilian Journal of Kinanthropometry and Human Performance. 2005;7(2):05-13. Portuguese.

18. Torquato JA, Lança AF, Pereira D, Carvalho FG, Silva RD. A aquisição da motricidade em crianças portadoras de Síndrome de Down que realizam fisioterapia ou praticam equoterapia. Fisioter Mov. 2013;26(3):51524. Portuguese.

19. Ribeiro J, Beltrame TS. Características neuromotoras e biopsicossocias de lactentes com histórico de risco biológico. Fisioter Mov. 2010;23(1):2534. Portuguese.

20. Sá CSC, Carvalho BC, Mazzitelli C. Equilíbrio e Coordenação Motora em Escolares Praticantes e Não Praticantes de Atividades Física e/ou Lúdica Extra-Escolar. Rev Neurocienc. 2014;22(1):29-36. Portuguese.

21. Medeiros JKB, Zanin RO, Alves KS. Perfil do Desenvolvimento Motor do Prematuro Atendido pela Fisioterapia. Rev Bras Clin Med. 2009;7:367-72. Portuguese. 
22. Nascimento R, Piassão C. Avaliação e estimulação do desenvolvimento neuropsicomotor em lactentes institucionalizados. Rev Neurocienc. 2010;18(4):46978. Portuguese.

23. Lamônica DAC, Picolini MM. Habilidades do Desenvolvimento de Prematuros. Rev CEFAC. 2009;11(supl.2):145-53. Portuguese.

24. Ribeiro ASC, Formiga CKMR, David AC. Healthy preterm infants: global motor coordination and early intervention. Fisioter Mov. 2015;28(1):85-95.

25. Papst JM, Marques I. Avaliação do desenvolvimento motor de crianças com dificuldades de aprendizagem. Brazilian Journal of Kinanthropometry and Human Performance. 2010;12(1):36-42. Portuguese.

26. Giaretta C, Becker SM, Fuentefria RN. Desenvolvimento Neuropsicomotor de lactentes prematuros vinculados à Clínica da Mulher de Chapecó. Rev Neurocienc. 2011;19(4):642-52. Portuguese.

27. Santos VAP, Vieira JLL. Prevalência de desordem coordenativa desenvolvimental em crianças com 7 a 10 anos de idade. Brazilian Journal of Kinanthropometry and Human Performance. 2013;15(2):23342. Portuguese.

28. Venetsanou F, Kambas A. Environmental Factors Affecting Preschoolers' Motor Development. Early Childhood Educ J. 2010;37(4):319-27.

29. Hallal CZ, Marques NR, Braccialli LMP. Aquisição de habilidades funcionais na área de mobilidade em crianças atendidas em um programa de estimulação precoce. Rev Bras Cresc Des Hum. 2008;18(1):2734. Portuguese.

30. Moreira RS, Magalhães LC, Alves CRL. Efeito do nascimento prematuro no desenvolvimento motor, comportamento e desempenho de crianças em idade escolar: revisão sistemática. J Pediatr. 2014;90(2):11934. Portuguese.

Received in 05/16/2014

Recebido em 16/05/2014

Approved in 11/05/2015

Aprovado em 05/11/2015 